\title{
Seasonal variations in microhabitat use and feeding habits of the pampas mouse Akodon azarae in agroecosystems of central Argentina
}

\author{
David N. BILENCA and Fernando O. KRAVETZ
}

\begin{abstract}
Bilenca D. N. and Kravetz F. O. 1998. Seasonal variations in microhabitat use and feeding habits of the pampas mouse Akodon azarae in agroecosystems of central Argentina. Acta Theriologica 43: 195-203.
\end{abstract}

We studied microhabitat use and food habits of the pampas mouse Akodon azarae (Fischer, 1829), in agroecosystems of central Argentina. In summer (breeding season), A. azarae inhabited both cropfields and their weedy borders. Sexually active females were caught at microhabitats with $31 \%$ more green cover than inactive ones. The percentage of invertebrates in the stomach contents of females was $104 \%$ greater than in males. In winter (non-breeding season), individuals were restricted to the borders, selecting sites with high levels of forbs and green cover. There were no significant differences between the sexes, either in microhabitat use or in food habits. We propose that reproduction of females is influenced by green cover, and that a decrease of this resource may reduce breeding activity of females in the borders after most plants enter senescence. Females would feed on insects as a source of proteins, which are required for reproduction. In winter, when the population is sexually inactive, individuals of both sexes have similar requirements and occupy the most suitable sites available within a low-quality habitat. We conclude that seasonal variations in microhabitat use and food habits of $A$. azarae are mainly influenced by changes in resource availability and reproductive status of individuals.

Departamento de Ciencias Biológicas, Facultad de Ciencias Exactas y Naturales, Universidad de Buenos Aires, Ciudad Universitaria, Pabellón II, 1428 Buenos Aires, Argentina; e-mail: dbilenca@biolo.bg.fcen.uba.ar

Key words: Akodon azarae, microhabitat use, food habits, seasonality, Argentina

\section{Introduction}

Seasonality is one of the major factors promoting variation in demography and resource use by rodent species (Kincaid and Cameron 1985, Ostfeld et al. 1985). Agroecosystems of the Pampean region in central Argentina show great seasonal variations in habitat structure. The schedule of agricultural practices in cropfields and the cover of grasses and forbs in the borders of cultivated areas are both primarily determined by seasonality (Busch and Kravetz 1992, Bonaventura and Cagnoni 1995).

The pampas mouse Akodon azarae (Fischer, 1829) is one of the most abundant species inhabiting the agroecosystems of the Pampean region. This species inhabits 
mainly cropfield edges, roadsides and fencerows (typically known as 'borders') and shows a strong seasonal variation in abundance, with a minimum in spring (October-November) and a maximum in late autumn and winter (late May-August), followed by a dramatic drop (Crespo 1966, Pearson 1967, Dalby 1975, Zuleta et al. 1988, Zuleta 1989, Mills et al. 1991, Busch and Kravetz 1992). Reproduction of A. azarae is also seasonal; the breeding season may last from 6 to 9 months (from September-October to April-June; Crespo 1966, Pearson 1967, Dalby 1975, Zuleta et al. 1988, Mills et al. 1992).

Little is known about how seasonality may influence the pattern of resource use of pampas mice. Previous studies observed intersexual variations in resource use during the breeding season (Bilenca et al. 1992, Bonaventura et al. 1992), which were attributed to differential investments and requirements of each sex in seeking reproductive success (Trivers 1972, Clutton-Brock et al. 1982). However, most previous studies of microhabitat use of $A$. azarae were restricted to the borders (Bonaventura and Kravetz 1989, Bonaventura et al. 1992, Bilenca et al. 1995), and information in cultivated areas is lacking. In this study we examined the interactions of a pampas mouse population with the varying conditions of the agroecosystems. Specific hypotheses addressed were: (1) variations in microhabitat use and food habits among seasons are directly related to habitat structure and resource availability, and (2) demographic subsets of the population (ie males and females, sexually active and inactive individuals) show differential patterns of resource use during the breeding season.

\section{Study area and methods}

Field work was carried out at Diego Gaynor (34 $\left.18^{\prime} \mathrm{S}, 59^{\circ} 14^{\prime} \mathrm{W}\right)$, NW Buenos Aires Province, Argentina. The study area belongs to the Pampa Ondulada, an agricultural region with moderate slopes (less than $2 \%$ ) and a temperate climate. Mean annual temperature is $16^{\circ} \mathrm{C}$, and annual rainfall averages $1000 \mathrm{~mm}$. Phytogeographically, the Pampa Ondulada belongs to the Pampean Province, Chacoan Domain, Neotropical Region (Cabrera 1953). The original vegetation consisted of matted grasses $0.5-1.0 \mathrm{~m}$ high, and trees were absent. Nowadays, the area is intensely cultivated, and most native plants are restricted to cropfield edges, roadsides and fencerows. Major summer crops are corn, soybeans, sunflower and sorghum. After harvest, fields are planted with winter-wheat, or left as stubble until spring.

Trapping was conducted at 3 cropfields ( 1 of preharvest corn and 2 of sunflower) and 5 borders between late February and early March (summer, breeding season), and at 2 cropfields (postharvest corn and sorghum) and 3 borders in late August 1992 (winter, non-breeding season). Trap sites were selected spanning the typical range of microhabitat variation available for rodents in each season (Bilenca 1993). Sherman live-traps were placed at $5 \mathrm{~m}$ intervals along traplines in each type of habitat. There were 30-60 stations per trapline. Traps were baited with a mixture of peanut butter and bovine fat, and checked daily for $3-5$ consecutive nights. Capture effort in summer was higher than in winter (3150 and 720 trap-nights, respectively), in order to have representative samples of rodents during low-density periods. Since capture effort differed among samplings, abundance of $A$. azarae was estimated by trapping success (number of captures / number of trap-nights; Mills et al. 1991). Each individual of $A$. azarae was sexed, and classified as reproductively active (males: scrotal 
testes; females: opened vagina, pregnant or lactating) or inactive (males: abdominal testes; females: closed vagina, neither pregnant nor lactating).

We placed additional traplines with snap-traps in cropfield and borders, in order to perform stomach content analyses of A. azarae. Snap-traps were located at least $500 \mathrm{~m}$ far from live-traps, and were baited with the same mixture as that used for live-trapping. Stomachs of snap-trapped individuals were removed and fixed in $70 \%$ ethanol. Procedures for stomach content analyses followed those of Bilenca et al. (1992): contents were boiled for 5 minutes, cleared in $50 \%$ sodium hypochlorite for 3 minutes, then washed, filtered with Whatman Grade 1 qualitative filter paper (retention: $11 \mu \mathrm{m}$ ) and spread on Petri dishes. Contents were examined at $12 \times$ and $50 \times$ magnification, and visual assessment was made of the relative (volumetric) quantities of seeds, invertebrates (mostly insects) and plant material; bait was removed and not counted in the measurements.

To describe the microhabitats available to pampas mice in cropfields and borders in each season, 12-30 $1-\mathrm{m}^{2}$-quadrats were randomly placed in each trapline. Five microhabitat variables were recorded for each quadrat as follows: $\%$ of grass cover (GRASS), $\%$ of forb cover (FORBS), $\%$ of green cover (GREEN), \% of bare ground (BAREG), and total volume of the vegetation, in $\mathrm{dm}^{3}$ (VOLUM), multiplying the area of total cover by the mean height of the vegetation. Dominant species and their phenological phases were also recorded.

To examine the microhabitat selection of $A$. azarae, we compared the distribution of frequencies of each microhabitat variable recorded at the trap sites where individuals of this species were captured with the median available in each type of habitat obtained from all quadrats, using the Wilcoxon signed rank test (Daniel 1978). Thus, microhabitat use of A. azarae was considered selective if any of the variables recorded was exploited disproportional to its availability (Johnson 1980, Litvaitis et al. 1994). Since livetrapping produced more than one capture of the same individual, we only considered the first capture of each individual to examine microhabitat ocurrence, thus avoiding dependence among data (Kincaid and Cameron 1985, Llewellyn and Jenkins 1987). Statistical comparisons in microhabitat use and food habits included ANOVA $F$-tests and Students $t$-tests for comparison of means of two samples with unknown variances not assumed equal (Bailey 1981: 49-51). Percentages of the vegetation variables (GRASS, FORBS, GREEN, and BAREG), and of the food items in the stomach contents were arcsin transformed prior to the analyses.

\section{Results}

\section{Analysis of vegetation}

Borders showed a sharp seasonal change in species composition of cover: in summer, grasses (Stipa hyalina, Cynodon dactylon, Paspalum dilatatum) and forbs (thistles, Bidens subalternans, Eryngium spp.) had nearly equal share in vegetation cover, whereas the latter prevailed in winter (Table 1). The volume of the vegetation in summer was highly significantly higher than in winter $(F=$ $309.58, p<0.001)$. On the other hand, borders had more green cover and less bare ground in winter than in summer $(t=3.38, p<0.05$ and $t=2.55, p<0.05$, respectively). Both seasonal changes were likely caused by the vegetative growth of winter forbs (Senecio spp., Baccharis pingraea), which show a dense cover at soil level.

In the cropfields, changes in vegetation and habitat structure were related to agricultural practices. In summer, crops were senescent (previous to the harvest) and weed grasses (Digitaria sanguinalis, Echinocloa crus-galli, Sorghum halepense) comprised the bulk of the green cover. After harvest, cropfields lost most 
Table 1. Mean ( \pm SD) values of microhabitat variables during summer (S) and winter $(W)$, for borders and cropfields in agroecosystems of Diego Gaynor, Argentina. GRASS - \% of grass cover, FORBS - \% of forb cover, GREEN - \% of green cover, VOLUM - total volume, in $\mathrm{dm}^{3} / \mathrm{m}^{2}$, BAREG - $\%$ of bare ground. ${ }^{*} p<0.05,{ }^{* *} p<0.01$ (ANOVA $F$-test). ${ }^{\wedge} \wedge p<0.01$ (Student's $t$-testis for two samples with unknown variances not assumed equal).

\begin{tabular}{|c|c|c|c|c|c|c|c|c|c|}
\hline \multicolumn{2}{|c|}{ GRASS } & \multicolumn{2}{|c|}{ FORBS } & \multicolumn{2}{|c|}{ GREEN } & \multicolumn{2}{|c|}{ VOLUM } & \multicolumn{2}{|c|}{ BAREG } \\
\hline $\mathrm{S}$ & $\mathrm{W}$ & $\mathrm{S}$ & $\mathrm{W}$ & $\mathrm{S}$ & W & $\mathrm{S}$ & W & $\mathrm{S}$ & $\mathrm{W}$ \\
\hline \multicolumn{10}{|c|}{ Borders ( $n=60$ in summer, $n=45$ in winter) } \\
\hline \multirow[t]{2}{*}{$45 \pm 25 * *$} & $21 \pm 24$ & $48 \pm 22 *$ & * $67 \pm 30$ & $56 \pm 14 \wedge \wedge$ & $68 \pm 30$ & $656 \pm 142 * *$ & $194 \pm 123$ & $26 \pm 19$ & $\wedge 18 \pm 18$ \\
\hline & $\wedge \wedge$ & ** & ** & * & ** & $\wedge \wedge$ & $\wedge \wedge$ & $\wedge \wedge$ & ** \\
\hline \multicolumn{10}{|c|}{ Crop areas ( $n=72$ in summer, $n=24$ in winter) } \\
\hline $50 \pm 32 \wedge \wedge$ & $0 \pm 0$ & $12 \pm 21$ & $15 \pm 15$ & $62 \pm 21 * *$ & $15 \pm 14$ & $367 \pm 194^{\wedge} \wedge$ & $22 \pm 17$ & $59 \pm 29$ & ^ $72 \pm 15$ \\
\hline
\end{tabular}

of their cover, the percentage of bare ground increased significantly, and the scarce seedlings of forbs provided most of the available green cover.

In general, the microhabitats of borders were more homogeneous and had more cover and less bare ground than those of the cropfields (Table 1). However, cropfields showed more green cover than borders in summer $(t=2.20, p<0.05)$, due to the different phenological phases of dominant species in each habitat type: in the cropfields, most species were still flowering or dispersing, whereas in the borders they entered senescence.

Trap success and breeding activity of Akodon azarae

Trap success of A. azarae in the borders increased from $1.6 \%$ in summer to $11.1 \%$ in winter. In summer, pampas mice had the same trap success in borders and cropfields, whereas in winter the population was almost absent in the cropfields $(0.2 \%)$. Eighty eight per cent of the males $(n=26)$ and $72 \%$ of the females ( $n=32$ ) were sexually active during the summer (pooling data from live and snap trapping; one female with uncertain reproductive status was excluded), while breeding activity dropped sharply to $0 \%$ in winter $(n=20$ and $n=15$, for males and females, respectively).

\section{Microhabitat use of Akodon azarae}

Altogether 57 trap sites of $A$. azarae were examined during the study period (Tables 2 and 3). In summer, microhabitat variables recorded in the borders at the capture sites of $A$. azarae showed no significant deviations from the microhabitat median, whereas in the cropfields pampas mice were highly selective, occupying grassy microhabitats, with scarce bare ground, and high levels of green cover and plant volume. Comparisons among sexes revealed no statistical differences in microhabitat use between males and females of $A$. azarae. However, 
Table 2. Microhabitat medians, and median values of microhabitat variables at the capture sites of A. azarae, classified by season and type of habitat. "+" indicates a significant selection of A. azarae for a certain variable (larger than microhabitat median), "_" means avoidance (smaller than microhabitat median). ${ }^{*} p<0.05,{ }^{* *} p<0.01$ (Wilcoxon signed rank test). Mnemonics of the variables as in Table 1.

\begin{tabular}{|c|c|c|c|c|c|c|}
\hline & $n$ & GRASS & FORBS & GREEN & VOLUM & BAREG \\
\hline \multicolumn{7}{|l|}{ Summer } \\
\hline Habitat: Borders & 60 & 43 & 45 & 60 & 640 & 20 \\
\hline A. azarae capture sites & 25 & 40 & 50 & 60 & 650 & 10 \\
\hline Habitat: Cropfields & 72 & 48 & 0 & 65 & 300 & 70 \\
\hline \multirow{2}{*}{ A. azarae capture sites } & 11 & 95 & 0 & 75 & 400 & 15 \\
\hline & & $+* *$ & & $+*$ & $+*$ & $-* *$ \\
\hline \multicolumn{7}{|l|}{ Winter } \\
\hline Habitat: Borders & 45 & 10 & 70 & 70 & 170 & 15 \\
\hline \multirow[t]{2}{*}{ A. azarae capture sites } & 21 & 5 & 85 & 75 & 230 & 10 \\
\hline & & & $+* *$ & $+* *$ & $+* *$ & \\
\hline
\end{tabular}

Table 3. Mean $( \pm \mathrm{SD})$ values of microhabitat variables at the capture sites of A. azarae, classified by season, sex and reproductive status. ${ }^{*} p<0.05$ (ANOVA $F$-tests). Mnemonics of the variables as in Table $1 .{ }^{a}$ One female with uncertain reproductive status was excluded from the analysis.

\begin{tabular}{|c|c|c|c|c|c|c|}
\hline & $n$ & GRASS & FORBS & GREEN & VOLUM & BAREG \\
\hline \multicolumn{7}{|l|}{ Summer } \\
\hline Males & 16 & $59 \pm 28$ & $39 \pm 30$ & $59 \pm 16$ & $614 \pm 195$ & $20 \pm 19$ \\
\hline Females & 20 & $59 \pm 36$ & $36 \pm 34$ & $63 \pm 16$ & $587 \pm 144$ & $17 \pm 17$ \\
\hline Active females ${ }^{a}$ & 12 & $58 \pm 42$ & $36 \pm 41$ & $\begin{array}{c}68 \pm 17 \\
*\end{array}$ & $550 \pm 158$ & $21 \pm 18$ \\
\hline Inactive females & 7 & $59 \pm 30$ & $36 \pm 22$ & $52 \pm 11$ & $654 \pm 106$ & $13 \pm 14$ \\
\hline \multicolumn{7}{|l|}{ Winter } \\
\hline Males & 12 & $11 \pm 18$ & $80 \pm 15$ & $78 \pm 15$ & $204 \pm 87$ & $15 \pm 11$ \\
\hline Females & 9 & $10 \pm 13$ & $80 \pm 16$ & $78 \pm 13$ & $286 \pm 199$ & $15 \pm 13$ \\
\hline
\end{tabular}

sexually active females were caught at microhabitats with $31 \%$ more green cover than inactive ones (68 and $52 \%$, for active and inactive females, respectively; $F=$ $4.49 p<0.05$, Table 3 ). The low numbers of sexually inactive males did not allow us to perform statistical comparisons of microhabitat use between males.

During the non-breeding season (winter), most $A$. azarae individuals were restricted to the borders, selecting microhabitats with greater values of FORB, GREEN and VOLUM than the microhabitat median. There were no significant differences between sexes in microhabitat use. 


\section{Food habits of Akodon azarae}

A. azarae showed significant seasonal shifts in the consumption of the cifferent food items (Table 4). In summer, the mean volumetric percentage of invertebrates in the stomach contents was greater than in winter $(t=3.20, p<0.01)$, whereas in the latter there was a greater percentage of plant material $(F=16.28, p<0.001)$.

During the breeding season, the mean volumetric percentage of invertebrates in the stomach contents of females was $104 \%$ greater than in males $(F=9.06$, $p<0.05$ ). Considering only sexually active individuals in the analysis, consumption of invertebrates by females was 2.7 times greater than males (sexually active females: mean $=49, \mathrm{SD}=23, n=11$, sexually active males: $18 \pm 18, n=7, F=$ $10.05, p<0.01$ ). There were no significant differences between the diets of males and females during the non-breeding season.

Table 4. Mean ( $\pm \mathrm{SD})$ volumetric percentages of seeds, invertebrates, and plant material in the stomach contents of $A$. azarae during summer (breeding season) and winter (non-breeding season). ${ }^{* *} p<0.01$ (ANOVA F-test), ${ }^{\wedge} \wedge p<0.01$ (Student's $t$-tests for two samples with unknown variances not assumed equal).

\begin{tabular}{lcccc}
\hline & $n$ & Seeds & Invertebrates & Plant material \\
\hline Summer & 23 & $24(26)$ & $\begin{array}{c}38(23) \\
\wedge \wedge\end{array}$ & $\begin{array}{c}36(23) \\
* * \\
\text { Winter }\end{array}$ \\
$\begin{array}{l}\text { Summer } \\
\text { Males }\end{array}$ & 14 & $15(23)$ & $15(10)$ & $70(24)$ \\
Females & 10 & $28(25)$ & $24(18)$ & $46(24)$ \\
Winter & 13 & $21(28)$ & $49(21)$ & $29(21)$ \\
Males & & & $11(5)$ & $69(30)$ \\
Females & 8 & $20(29)$ & $19(13)$ & $71(15)$ \\
\hline
\end{tabular}

\section{Discussion}

During the study, A. azarae showed great variations in population abundance and habitat distribution, reflecting both temporal and spatial changes in habitat quality and reproduction. The considerable drop in trap success in the cropfields during winter reveals that harvesting of cultivated areas makes the habitat unsuitable for $A$. azarae populations, whereas the high abundance in borders is a consequence of the recruitment that took place during the breeding season and postharvest recolonization from agricultural areas. These results are in agreement with previous studies showing that borders are the only type of habitat which can provide year-round favorable habitat for A. azarae (Zuleta et al. 1988, Mills et al. 1991, Busch and Kravetz 1992). However, cropfields may act as a temporarily 
suitable habitat prior to the harvest, as revealed by the microhabitat selection of A. azarae for grassy sites in the crop areas (Table 2).

The higher level of green cover recorded at the capture sites of active females as compared with inactive ones during the breeding season (Table 3), is consistent with evidence from a livetrapping study conducted at the borders by Bonaventura et al. (1992). These authors found a negative correlation between the average distance travelled by females of $A$. azarae and the green foliage density recorded at the trap sites, and considered that green cover was an important resource for home-range election in A. azarae females. According to our results, the significantly higher proportion of pregnant female A. azarae in cultivated habitats as compared to the borders (Mills et al. 1992) could be related to the higher level of green cover in the former habitat (Table 1). Although we have no direct evidence to explain the effect of green cover in the breeding success of females of pampas mice, available evidence allow us to propose that reproduction of $A$. azarae females is influenced by green cover, and that a decrease of this resource may reduce the breeding activity of sexually active females in the borders after most plant species enter senescence.

In winter, many of the sites covered by forbs which are selected by A. azarae at the borders offer soft shoots (food), and provide high vegetation volume at ground level (Table 2). The selection of $A$. azarae for this type of microhabitats may have great adaptive significance, considering that, in winter, food availability is a limiting factor (Cittadino et al. 1994) and since frosts and low temperatures induce great rodent mortality (Crespo 1944, Dalby and Heath 1976).

The great seasonal variation in food habits of $A$. azarae (Table 4) reflects the high opportunism of the species in switching to those food items which are more abundant at a particular time, ie, more consumption of invertebrates in summer and more plant consumption in winter (Bilenca et al. 1992). Even though food habits of pampas mice are greatly influenced by food availability, the difference in the consumption of invertebrates between sexes observed in the breeding season reveals that $A$. azarae female are able to exploit food resources selectively. The higher consumption of invertebrates by females suggests that females of pampas mice feed on insects as a source of proteins, thus meeting both energetic and nutrient requirements for reproduction (Hoffmann 1958, Bomford and Redhead 1987).

In summary, we have observed that $A$. azarae shows a great seasonal variation in the pattern of resource use in agroecosystems of central Argentina. Available evidence suggests that differences in the pattern of resource use between the breeding and the non-breeding seasons can be explained by both changes in individual requirements and habitat structure. In A. azarae, as in many polygynous mammals (Suárez 1996), each gender has different constraints on reproductive success, leading to sex-specific reproductive tactics (Trivers 1972, Clutton-Brock et al. 1982, Ostfeld et al. 1985). For females, reproductive performance would rely on their ability to acquire specific resources (green cover, insects), while repro- 
ductive performance of males would depend on their ability to be accepted by females for copulation, and probably not directly related to the abundance and distribution of resources (Zuleta 1989, Zuleta and Bilenca 1992, Bonaventura et al. 1992, this study). It can be suggested that during the non-breeding season, with harsher environmental conditions, all individuals have similar requirements. Thus, both sexes seek similar microhabitats which provide the highest levels of shelter and food. Clarification of these hypotheses must await experimental studies including manipulations of green cover in the field, along with feeding trials and assessment of the reproductive performance of $A$. azarae in the laboratory.

Acknowledgements: We are grateful to M. Busch, G. R. Cueto, G. A. Zuleta and 4 anonymous reviewers for reading and commenting on the manuscript. This study was funded by grants of the University of Buenos Aires and the Consejo Nacional de Investigaciones Científicas y Técnicas (CONICET, Argentina).

\section{References}

Bailey N. T. J. 1981. Statistical methods in biology. Second edition, Hodder and Stoughton, London: 1-216.

Bilenca D. N. 1993. Caracterización de los nichos ecológicos y organización de las comunidades de roedores cricétidos de la región pampeana. $\mathrm{Ph} \mathrm{D}$ thesis, University of Buenos Aires: 1-179+95.

Bilenca D. N., Cittadino E. A. and Kravetz F. O. 1995. Influencia de la actividad de Cavia aperea sobre la estructura del habitat y la distribución de Akodon azarae y Oryzomys flavescens (Rodentia: Cavidae, Muridae) en bordes de cultivos de la región pampeana (Argentina). Iheringia, Serie Zoologia, (Porto Alegre) 79: 67-75.

Bilenca D. N., Kravetz F. O. and Zuleta G. A. 1992. Food habits of Akodon azarae and Calomys laucha (Cricetidae, Rodentia) in agroecosystems of central Argentina. Mammalia 56: 371-383.

Bomford M. and Redhead T. 1987. A field experiment to examine the effects of food quality and population density on reproduction of wild house mouse. Oikos 48: 304-311.

Bonaventura S. M. and Cagnoni M. C. 1995. La vegetación de los bordes de caminos en agroecosistemas. Physis (Buenos Aires), Sección C, 50: 63-71.

Bonaventura S. M. and Kravetz F. O. 1989. Relación roedor-vegetación: importancia de la disponibilidad de cobertura verde para Akodon azarae durante el invierno. Physis (Buenos Aires), Sección C, 47: 1-5.

Bonaventura S. M., Kravetz F. O. and Suárez O. V. 1992. The relationship between food availability, space use and territoriality in Akodon azarae. Mammalia 56: 407-416.

Busch M. and Kravetz F. O. 1992. Competitive interactions among rodents (Akodon azarae, Calomys laucha, Calomys musculinus and Oligoryzomys flavescens) in a two habitat system. Spatial and numerical relationships. Mammalia 56: 45-56.

Cabrera A. 1953. Esquema fitogeográfico de la República Argentina. Revista del Museo La Plata (Botánica) 8: 87-168.

Cittadino E. A., De Carli P., Busch M. and Kravetz F. O. 1994. Effects of food supplementation on rodents in winter. Journal of Mammalogy 75: 446-453.

Clutton-Brock T. H., Guinness F. E. and Albon S. D. 1982. Red deer: behavior and ecology of two sexes. Wildlife behavior and ecology series. The University of Chicago Series, Chicago: 1-378.

Crespo J. A. 1944. Relaciones entre estados climáticos y la ecología de algunos roedores de campo (Cricetidae). Revista Argentina de Zoogeografia 4: 137-144.

Crespo J. A. 1966. Ecología de una comunidad de roedores silvestres en el Partido de Rojas, Provincia de Buenos Aires. Revista del Museo de Ciencias Naturales "Bernardino Rivadavia", Ecología, 1: 79-134. 
Dalby P. 1975. Biology of Pampa rodents. Publications of the Museum of Michigan State University, Biological Series, 5: 149-271.

Dalby P. and Heath A. G. 1976. Oxygen consumption and body temperature of the Argentina field mouse, Akodon azarae, in relation to ambient temperature. Journal of Thermal Biology 1: 177-179.

Daniel W. W. 1978. Applied nonparametric statistics. Houghton Mifflin Co., Boston: 1-503.

Hoffmann R. S. 1958. The role of reproduction and mortality in population fluctuations of voles (Microtus). Ecological Monographs 28: 79-109.

Johnson D. H. 1980. The comparison of usage and availabilty measurements for evaluating resource preference. Ecology 61: 65-71.

Kincaid W. B. and Cameron G. N. 1985. Interactions of cotton rats with a patchy environment: dietary responses and habitat selection. Ecology 66: 1769-1783.

Litvaitis J. A., Titus K. and Anderson E. M. 1994. Measuring vertebrate use of terrestrial habitats and foofs. [In: Research and management techniques for wildlife and habitats. T. A. Bookhout, ed]. The Wildlife Society, Bethesda: 254-274.

Llewellyn J. B. and Jenkins S. H. 1987. Patterns of niche shift in mice: seasonal changes in microhabitat breadth and overlap. American Naturalist 129: 365-381.

Mills J. N., Ellis B. A., Mckee K. T. Jr, Maiztegui J. I. and Childs J. E. 1991. Habitat associations and relative densities of rodent populations in cultivated areas of central Argentina. Journal of Mammalogy 72: 470-479.

Mills J. N., Ellis B. A., Mckee K. T. Jr, Maiztegui J. I. and Childs J. E. 1992. Reproductive characteristics of the rodent community in cultivated areas of central Argentina. Journal of Mammalogy 73: 515-526.

Ostfeld R. S., Lidicker W. Z. Jr and Heske E. J. 1985. The relationship between habitat heterogeneity, space use, and demography in a population of California voles. Oikos 45: 433-442.

Pearson O. P. 1967. La estructura por edades y la dinamica reproductiva en una poblacion de ratones de campo, Akodon azarae. Physis (Buenos Aires), Sección C, 27: 53-58.

Suárez O. V. 1996. Estrategias reproductivas y cuidado parental en Akodon azarae (Rodentia, Muridae). Ph D thesis, University of Buenos Aires, Buenos Aires: 1-215.

Trivers R. L. 1972. Parental investment and sexual selection. [In: Sexual selection and the descent of man. B. Campbell, ed]. Aldine Press, Chicago: 136-179.

Zuleta G. A. 1989. Estrategias de historia de vida en el ratón del pastizal pampeano, Akodon azarae. $\mathrm{Ph}$ D thesis, University of Buenos Aires, Buenos Aires: 1-256.

Zuleta G. A., Kravetz F. O., Busch M. and Percich R. E. 1988. Dinámica poblacional del ratón del pastizal pampeano (Akodon azarae), en ecosistemas agrarios de Argentina. Revista Chilena de Historia Natural 61: 231-244.

Zuleta G. A. and Bilenca D. N. 1992. Seasonal shifts within juvenile recruit sex ratio of Pampas mice (Akodon azarae). Journal of Zoology, London 227: 397-404. 